\title{
THE SIGNIFICANCE OF ANTIBODY COATED BACTERIA IN NEUROPATHIC BLADDER URINES
}

\author{
By Rosemary Lindan, M.B., B.S. \\ Spinal Cord Injury Service, Cuyahoga County Hospitals, \\ Highland View Division, Cleveland, Ohio 44I09, U.S.A.
}

\begin{abstract}
A total of 234 patients with neuropathic bladder dysfunction and bacteria in the urine have been studied for the presence of antibody coating on the bacteria. Approximately one third of the patients so studied were found to have antibody coated bacteria in the urine $(\mathrm{ACB}+)$ by fluorescent microscopy. No correlation could be found between evidence of active tissue infection by the ACB test and the age, sex or catheter status of the patient, the radiological findings or the length of time since the neurological injury. There did, however, appear to be significant differences among the bacterial species isolated, in their ability to invade through urothelium. Testing for antibody coating is a useful epidemiological tool, but is not indicated for routine use as a guide to therapy. The choice of antibacterial drugs can, in most instances, be based on the identification of the bacterial isolate and its known potential for invasion of the upper urinary tract.
\end{abstract}

Key words: Antibody-coated bacteria; Neuropathic bladder infections.

\section{Introduction}

A SIMPLE, non-invasive technique claimed to detect active infection of the upper urinary tract was described by Thomas, Shelokov \& Forland in 1974. Based on the findings of Pearsall \& Sherris (I966) that bacteria reaching the kidney stimulate the production of antibody to the bacterial O-antigen, they applied fluoresceintagged antihuman-globulin antibody to washed bacteria in freshly obtained urine sediments. Any bacteria which have been coated with antibody globulin will, by this technique, appear as fluorescent when viewed under a U.V.-light microscope. Jones, Smith \& Sanford (I974) reported finding a high degree of correlation between antibody coating and infected ureteral specimens of urine, indicating that antibody coating of bacteria occurs in the kidney.

Since 1974, we have studied 234 patients with neuropathic bladder dysfunction with the object of determining the incidence of antibody coated bacteria in their urines, firstly as it relates to other evidence of renal infection and secondly as it relates to the types of bacteria isolated.

\section{Method}

The method we used was that of Thomas and her associates. Wet sediments were examined under both dark field and U.V. illumination, using fluoresceintagged horse-antihuman globulin (Roboz) or goat-antihuman globulin (Miles Laboratories). 'Blocking' antibody (Difco), cultured isolates and urine sediments from proven cases of pyelonephritis were used as controls.

All urine specimens were obtained by bladder catheterisation. Following the aseptic insertion of a sterile urethral catheter the bladder was rinsed three times with $50 \mathrm{ml}$ of sterile saline and the catheter was then clamped for 30 minutes before 
obtaining the specimen. This precaution is necessary in order to avoid contamination from organisms residing in the prostate or urethral canal which, it has been shown, may also acquire antibody coating (Jones, I974).

\section{Study group}

Among the patients studied were 193 men and $4 \mathrm{I}$ women ranging in age from the teens to the 70s during the study period, with an average age of $20-30$ years. Their injuries dated from as recently as 2 months to as long as I 4 years before, with an average of 4 years. All the patients had had indwelling Foley catheters at one time (and 70 still used them), while I64 had become catheter-free at the time of the study.

There were I Io paraplegics and I03 tetraplegics with complete lesions and 2 I patients with other neurological lesions (central cord syndromes, transverse myelitis and incomplete cord transections).

None of the patients was receiving therapeutic antibacterials at the time the urine specimens were obtained. The majority were on a permanent regimen of urinary acidifiers and urinary antiseptics in suppressive doses, aimed at preventing bacterial multiplication in the bladder but had not received any of these agents for the 12 hours preceding the test.

\section{Results and Discussion}

In 34 per cent, or one third of the 234 patients, the urine specimens obtained were found to be positive for antibody coated bacteria $(\mathrm{ACB}+)$.

No correlation could be found between this evidence of active tissue infection and the age, sex or catheter status of the patients, nor the length of time since the cord injury.

The relationship between radiological evidence of upper tract disease and antibody coating of bacteria is shown in Table I. When the radiological picture was negative, the majority of cases were also negative for antibody coated bacteria in the urine, but a minority of more than 20 per cent were positive. On the other hand when the X-rays did show evidence of calyceal blunting we found that over 70 per cent of these patients had urine with bacteria which were negative for antibody coating. Thus, assuming that antibody coating indicates active upper

\section{TABLE I}

Relationship of ACB to X-ray evidence of calyceal blunting in 125 spinal-cord injury patients

\begin{tabular}{ccc}
\hline ACB & \multicolumn{2}{c}{ Intravenous pyelograms } \\
\cline { 2 - 3 } & Abnormal & Normal \\
Positive & - & \\
30 cases & 9 cases & 2 c cases \\
$(24 \%)$ & $(30 \%)$ & $(70 \%)$ \\
Negative & & \\
95 cases & 23 cases & 72 cases \\
$(76 \%)$ & $(24 \%)$ & $(78 \%)$ \\
\hline
\end{tabular}


tract infection, it would appear that IVP appearances are a rather poor guide to the presence or absence of active kidney infections.

We did find a very significant correlation between the genus of the bacterial isolates and their ability as judged by this test, to invade the tissues of the urinary tract. They appeared to fall quite clearly into three groups (Table II). On the assumption that antibody coated bacteria, detected by this method, denote the presence of active upper urinary tract infection, we can advance the hypothesis that 50 per cent of our patients with E. coli and proteus infections have upper tract

\section{TABLE II}

Incidence of antibody coating as related to bacterial species isolated from urine cultures of patients with spinal cord injury

\begin{tabular}{lcc}
\hline Infecting bacterial species & $\mathrm{ACB}+$ & $\mathrm{ACB}-$ \\
\cline { 2 - 3 } Escherichia coli & 20 & $\mathrm{I} 9$ \\
Proteus mirabilis & 25 & 26 \\
Klebsiella pneumonii & 24 & 3 \\
Enterobacter aerog/cloacae & 9 & 2 \\
Serratia marcescens & $\mathrm{I}$ & 22 \\
Pseudomonas aeruginosa & 0 & 63 \\
Enterococci sp. & 0 & $\mathrm{IO}$ \\
Citrobacter freundii & 0 & $\mathrm{IO}$ \\
& & \\
Total no. of isolates & 79 & $\mathrm{I} 55$ \\
\hline
\end{tabular}

involvement. Among klebsiella or enterobacter strains the great majority were $\mathrm{ACB}+$, indicating that these organisms probably have the highest virulence in this type of patient and that such infections should therefore be treated promptly and vigorously. By contrast, the classically opportunist organisms such as pseudomonas, serratia, providencia stuartii or citrobacter were practically never antibody coated, even on retesting over periods of 6 months to 2 years of continuous carriage. These organisms are all highly resistant to the more common antibacterials but, on the basis of our findings, it would seem that the isolation of such organisms from the urines of patients with a neuropathic bladder does not necessarily, nor usually, warrant therapy with toxic or expensive antibiotic drugs.

\section{Summary}

The testing of urine sediments from patients with neurogenic bladder dysfunction for the presence of antibody coated bacteria is an important tool in epidemiological studies, since it appears to be a more sensitive indicator of early renal infection than radiological studies. It is a time-consuming test and it is probably not necessary to perform it in every individual case as a guide to treatment. The advisability of selecting antibacterial drugs which are active in renal tissue can probably be better deduced in this type of patient from the species of the infecting bacteria.

\section{RÉSUMÉ}

Deux cents trente quatre patients atteints d'une dysfonction neurologique de la vessie urinaire et dont l'urine contenait les bactéries, ont étudié pour la présence d'une couche anticorps sur les bactéries (ACB). La microscopie fluorescente a révélé une couche 
d'anticorps bacteriens dans environs un tiers des cas étudiés. On n'a pas trouvé de corrélation entre l'infection active des tissus, mise en évidence en testant la présence d'ACB, et l'âge ou le sexe du patient, la présence ou absence de catheter, les constations radiologiques ou le lapse de temps écoulé depuis la lésion neurologique. Cependant, les tests ont montré des différences importantes entre les types de bactéries isolés dans leur capacité de pénétrer l'épithelium urinaire.

Les ACB tests sont un util épidémiologique utile, mais ne sont pas recommendés en tant qu'indicer pour le traitement. Le choix des bactéricides devrait être fondé sur l'identification de l'isolant bactérien et sur son potentiel de pénétration de la voie urinaire supérieur.

\section{ZUSAMMENFASSUNG}

Zwei hundert und vierunddreissig Patienten mit Blasenlähmung und mit Bakterien im Urin wurden auf Vorhandensein von Antikörper 'coating' untersucht. Ungefähr ein Drittel der so untersuchten Patienten hatten Bakterien mit Antikörper 'coating' (ACB +) under dem Fluoreszenz Mikroskop. Es bestand keine Wechselbeziehung zwischen aktiver Gewebsentzündung mittels des ACB Tests, und Alter, Geschlecht, Katheterstatus, roentgenologischem Befund oder Zeitdauer seit dem Unfall. Jedoch wurden wichtige Unterschiede unter den isolierten Bakterienspezies in ihrer Fähigkeit, in das Blasenepithel einzudringen gefunden. Untersuchung auf Antikörper 'coating' ist epidemiologisch nützlich, aber keine Richtlinie zur Therapie. Die Wahl einer bakterienfeindlichen Droge beruht auf Identifizierung der Bakterien und deren Fähigkeit, in den oberen urogenitalen Trakt eizudringen.

\section{REFERENCES}

JoNES, S. R., SMITH, J. W. \& SANFoRD, J. P. (I974). Localization of urinary tract infections by detection of antibody-coated bacteria in urine sediment. New Eng. F. Med., 290, $591-593$.

JONES, S. R. (1974). Prostatitis as cause of antibody-coated bacteria in urine. New Eng. F. Med., 291, 365.

Pearsall, N. N. \& Sherris, J. C. (1966). The demonstration of specific urinary antibodies in urinary tract infections caused by gram negative bacilli. F. Pathol. Bacteriol., 91, $589-595$.

Thomas, V., Shelokov, A. \& Forland, M. (1974). Antibody-coated bacteria in the urine and the site of urinary tract infection. New Eng. F. Med., 290, 588-590. 